\title{
An Evaluation of the Importance of Gastric Acid Secretion in the Absorption of Dietary Calcium
}

\author{
George W. Bo-Linn, Glenn R. Davis, David J. Buddrus, \\ Stephen G. Morawski, Carol Santa Ana, \\ and John S. Fordtran \\ Department of Internal Medicine, Baylor University Medical \\ Center, Dallas, Texas 75246
}

bstract. Since calcium solubility is a prerequisite to calcium absorption, and since solubility of calcium is highly $\mathrm{pH}$-dependent, it has been generally assumed that gastric acid secretion and gastric acidity play an important role in the intestinal absorption of calcium from ingested food or calcium salts such as $\mathrm{CaCO}_{3}$. To evaluate this hypothesis, we developed a method wherein net gastrointestinal absorption of calcium can be measured after ingestion of a single meal. A large dose of cimetidine, which markedly reduced gastric acid secretion, had no effect on calcium absorption in normal subjects, and an achlorhydric patient with pernicious anemia absorbed calcium normally. This was true regardless of the major source of dietary calcium (i.e., milk, insoluble calcium carbonate, or soluble calcium citrate). Moreover, calcium absorption after $\mathrm{CaCO}_{3}$ ingestion was the same when intragastric contents were maintained at pH 7.4 (by in vivo titration) as when intragastric $\mathrm{pH}$ was 3.0 . On the basis of these results, we conclude that gastric acid secretion and gastric acidity do not normally play a role in the absorption of dietary calcium. Other possible mechanisms by which the gastrointestinal tract might solubilize ingested calcium complexes and salts are discussed.

\section{Introduction}

Most dietary calcium is bound in complex formations with other food constituents, e.g., calcium caseinate in milk (1). For this calcium to be absorbed, these complexes must be dissociated by digestive enzymes and the calcium released in a soluble and

Received for publication 28 February 1983 and in revised form 17 October 1983.

J. Clin. Invest.

(c) The American Society for Clinical Investigation, Inc. 0021-9738/84/03/0640/08 $\$ 1.00$

Volume 73, March 1984, 640-647 probably in an ionized form $(1,2)$. Moreover, calcium salts (whether preexisting in food or formed from the interaction of different food constituents) are relatively insoluble in water and must therefore be dissolved before calcium absorption can occur (3). Since both the dissociation of food-calcium complexes and the solution of calcium salts are highly dependent on an acid pH, it has generally been assumed that gastric acid secretion plays an important role in calcium absorption $(1,4)$.

For calcium salts, which are relatively water-insoluble (such as the carbonate and the phosphate), gastric acid secretion is believed to play a critical role in calcium absorption. Clarkson et al. (5) postulated that ingested calcium carbonate reacts with hydrochloric acid to form soluble calcium chloride, part of which is absorbed in the small intestine while the remainder is converted back to calcium carbonate in the lower intestine.

$$
\begin{gathered}
\mathrm{CaCO}_{3}+2 \mathrm{HCl} \rightarrow \mathrm{CaCl}_{2}+\mathrm{H}_{2} \mathrm{O}+\mathrm{CO}_{2} \\
\mathrm{CaCl}_{2}+2 \mathrm{NaHCO}_{3} \rightarrow \mathrm{CaCO}_{3}+2 \mathrm{NaCl}+\mathrm{CO}_{2}+\mathrm{H}_{2} \mathrm{O}
\end{gathered}
$$

According to this hypothesis, the amount of calcium absorbed after ingestion of $\mathrm{CaCO}_{3}$ should be proportional to the acidity of the upper gastrointestinal contents (which is determined mainly by the rate of gastric secretion). In the absence of acid, $\mathrm{CaCO}_{3}$ should remain insoluble, and as such, calcium given in this form should be poorly absorbed. Accordingly, one authoritative source states flatly that "calcium carbonate will not be absorbed by patients with achlorhydria" (6).

Although it is logical to presume that gastric acidity and acid secretion play a major role in the absorption of calcium from food and calcium salts, this concept has never been systematically examined. The importance of this issue is apparent when one considers the deleterious effects of calcium malabsorption, the fact that the most popular calcium supplements consist of $\mathrm{CaCO}_{3}$, the high prevalence of hypo- and achlorhydria (especially in elderly women) (7), and the frequency with which potent gastric antisecretory drugs are prescribed (often for long periods of time). To study the role of gastric acid on calcium absorption, we devised a method that permits measurement of net intestinal absorption of dietary calcium after ingestion of a single meal. 


\section{Methods}

\section{Overview}

The method begins with a preparatory washout wherein the subject's entire gastrointestinal tract is cleansed by lavage. The subject then eats a meal, which includes polyethylene glycol (PEG) ${ }^{1}$ as a nonabsorbable marker. After $12 \mathrm{~h}$, the intestine is cleansed again by a final washout, and the rectal effluent is combined with any stool (usually none) that was excreted since the meal was eaten. The meal and rectal effluent are analyzed for calcium. The completeness of collection is evaluated by recovery of the nonabsorbable marker. On a separate day, the entire procedure is repeated, except that only water containing the nonabsorbable marker is ingested (i.e., no food or calcium is ingested); this provides an estimate of the amount of calcium in the rectal effluent that is not attributable to eating the meal.

We then calculate net calcium absorption ${ }^{2}$ according to the following equation:

Net calcium absorption $=$ Amount of calcium ingested

- (Effluent calcium after meal - Effluent calcium after fast).

For example, assume that on test day 1 , after the preparatory washout, the subject ingested $1,000 \mathrm{mg}$ of calcium, and the rectal effluent from the final washout contained $800 \mathrm{mg}$ of calcium; on test day 2 , the subject fasted after the preparatory washout, and the effluent contained $40 \mathrm{mg}$ of calcium. Substituting in the equation,

$$
\text { Net calcium absorption }=1,000-(800-40)=240 \mathrm{mg} .
$$

\section{Subjects}

16 normal, healthy subjects ( 12 men, 4 women) were studied. Mean ( \pm SEM) age was $28 \pm 1$ yr with a range of $21-36$. We also studied a postmenopausal woman, age 57 , who has pernicious anemia and receives monthly vitamin $B_{12}$ injections. After subcutaneous injection of pentagastrin $(6 \mu \mathrm{g} / \mathrm{kg}$ body weight), she had gastric achlorhydria (lowest $\mathrm{pH}$ of gastric aspirate was 7.4). Four patients with chronic renal disease on hemodialysis took part in the validation studies reported in Figs. 1 and 2; these patients did not take part in any of the experiments related to the effect of gastric acid on intestinal absorption of calcium.

This project was approved by the Institutional Review Board for Human Protection at Baylor University Medical Center, and written informed consent was received from each participant.

\section{Test meals}

The low calcium meal consisted of $170 \mathrm{~g}$ of sirloin steak, seasoned with salt and pepper, $25 \mathrm{~g}$ of white bread with $5 \mathrm{~g}$ margarine, $40 \mathrm{~g}$ of lettuce with $30 \mathrm{~g}$ French salad dressing, $250 \mathrm{ml}$ of tea with $5 \mathrm{~g}$ of sugar, and $10 \mathrm{~g}$ of PEG. By our measurements, this meal contained $71 \pm 1 \mathrm{mg}$ of calcium $(n=4$, range $70-72 \mathrm{mg})$. The high calcium meal was the same except that $250 \mathrm{ml}$ of skim milk was substituted for the tea and $57 \mathrm{~g}$ of Swiss cheese was melted on the steak. The high calcium meal contained $852 \pm 1 \mathrm{mg}$ of calcium ( $n=4$, range $850-856 \mathrm{mg}$ ). A third meal that contained $290 \pm 3 \mathrm{mg}$ of calcium ( $n=5$, range 284 to 298

1. Abbreviations used in this paper: PEG, polyethylene glycol.

2. Net absorption is defined as dietary intake minus fecal excretion. True absorption exceeds net absorption because some endogenously secreted calcium is reabsorbed.

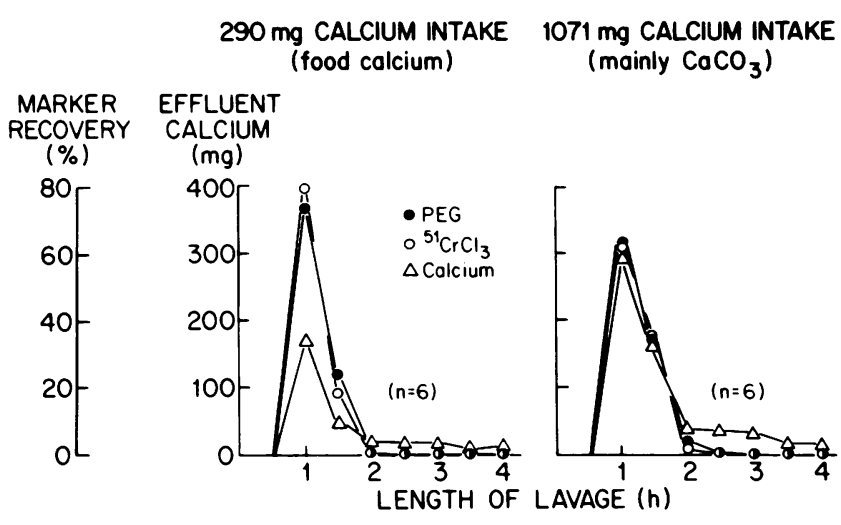

Figure 1. Mean timed recoveries of PEG, ${ }^{51} \mathrm{CrCl}_{3}$, and calcium in lavage effluents from six subjects after ingesting $290 \mathrm{mg}$ of food calcium (left), and $1,071 \mathrm{mg}$ of calcium as $71 \mathrm{mg}$ of food calcium supplemented with $1,000 \mathrm{mg}$ of calcium as $\mathrm{CaCO}_{3}$ (right).

$\mathrm{mg}$ ) was used in validation studies only. This meal consisted of $57 \mathrm{~g}$ of sirloin steak, $25 \mathrm{~g}$ of white bread, $40 \mathrm{~g}$ of lettuce with $30 \mathrm{~g}$ of French salad dressing, $30 \mathrm{~g}$ of Swiss cheese, $250 \mathrm{ml}$ of tea with $5 \mathrm{~g}$ of sugar, and $10 \mathrm{~g}$ of PEG.

\section{Calcium supplements}

The low calcium meal was supplemented with either calcium carbonate or calcium citrate. The calcium carbonate was provided in Os-Cal tablets (Marion Laboratories, Kansas City, MO), which did not contain added vitamin $\mathrm{D}$. The source of calcium carbonate in Os-Cal tablets is crushed oyster shell. Os-Cal tablets disperse rapidly in water, but calcium carbonate is negligibly soluble in water. To study the effect of $\mathrm{HCl}$ and $\mathrm{pH}$ on the solubility of calcium carbonate in oyster shell tablets, we measured the amount of $0.1 \mathrm{~N} \mathrm{HCl}$ required to maintain $\mathrm{pH}$ constant at various set points, when an Os-Cal tablet was placed in a beaker containing 100 $\mathrm{ml}$ of water. The amount of $\mathrm{HCl}$ required to maintain the $\mathrm{pH}$ constant at a given level reflects the amount of calcium carbonate that has gone into solution at that $\mathrm{pH}(8)$. As shown in Table $\mathrm{I}$, reducing $\mathrm{pH}$ from

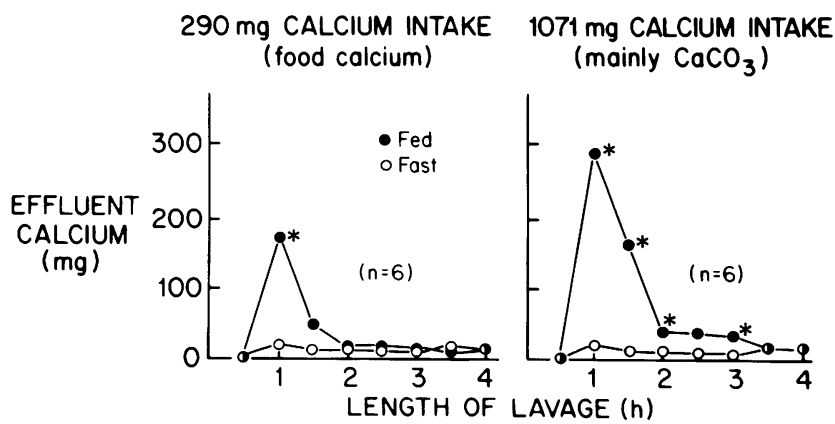

Figure 2. Mean timed recoveries of calcium in lavage effluents from six subjects after fasting and after ingesting $290 \mathrm{mg}$ of food calcium (left) and after $1,071 \mathrm{mg}$ of calcium as $71 \mathrm{mg}$ of food calcium supplemented with $1,000 \mathrm{mg}$ of calcium as $\mathrm{CaCO}_{3}($ right $) . *, P<0.05$ by paired $t$ test. 
Table I. Volume of $0.1 \mathrm{~N} \mathrm{HCl}$ Required to Maintain pH at Various Set Points When One Oyster Shell Tablet Was Added to $100 \mathrm{Ml}$ Water

\begin{tabular}{rlrrr}
\hline & \multicolumn{5}{c}{$\mathrm{pH}$ set point } \\
\cline { 2 - 5 } Time & 7.4 & \multicolumn{1}{c}{6} & \multicolumn{1}{c}{4} & \multicolumn{1}{c}{3} \\
\hline $\min$ & & & & \\
10 & 0 & 3.1 & 1.7 & 5.2 \\
20 & 0.1 & 12.3 & 11.7 & 27.8 \\
40 & 0.1 & 33.9 & 60.4 & 91.0 \\
60 & 0.1 & 60.3 & 86.6 & 140.6 \\
80 & 0.1 & 74.3 & 93.9 & 172.2 \\
100 & 0.1 & 87.6 & 111.2 & 190.4 \\
120 & 0.1 & 93.0 & 131.8 & 202.2 \\
& & & &
\end{tabular}

Theoretically, $250 \mathrm{ml}$ of $0.1 \mathrm{~N} \mathrm{HCl}$ is sufficient to completely solubilize the calcium carbonate contained in one oyster shell tablet $(1.25 \mathrm{~g}$ of $\mathrm{CaCO}_{3}$ or $500 \mathrm{mg}$ of elemental calcium). Hence, for example, after 120 min at $\mathrm{pH} 6,37 \%(93 / 250 \times 100)$ of the calcium carbonate had reacted with $\mathrm{HCl}$ and gone into solution as $\mathrm{CaCl}_{2}$.

7.4 to 6.0 or 3.0 was associated with a marked increase in calcium carbonate solubility, as assessed by this test.

The calcium citrate supplement originated from effervescent tablets prepared by Miles Laboratories, Inc., Elkhart, IN. These tablets contain calcium carbonate and citric acid. When added to water, they effervesce, thus liberating calcium citrate. The latter is soluble in water, and the calcium is present in ionized form.

The calcium carbonate tablets were swallowed with $200 \mathrm{ml}$ of water. The effervescent tablets were added to $200 \mathrm{ml}$ of water, after effervescence ceased, the subjects drank the calcium citrate solution. Unless otherwise stated, the subjects took the calcium supplements $1 \mathrm{~h}$ after beginning to eat the meal.

\section{Procedure}

After an overnight fast, the subjects underwent the preparatory washout with Golytely (Braintree Scientific, Inc., Braintree, MA), a lavage solution that is not associated with either net intestinal absorption or secretion of water and electrolytes (9). We administered Golytely orally $(300 \mathrm{ml}$ every $10 \mathrm{~min}$ ) or by intragastric infusion $(30 \mathrm{ml}$ per $\mathrm{min})$ through a mercury weighted, polyvinyl tube that the subject swallowed. After $4 \mathrm{~h}$ of Golytely lavage, the rectal effluent was totally clear and contained no unabsorbed dietary nutrients (previous studies from our laboratory). The rectal effluent from the first washout was discarded.

$4 \mathrm{~h}$ after completion of the first lavage, the subject ate the test meal. $12 \mathrm{~h}$ after the meal, without further ingestion of food or drink, the subjects underwent a second (final) lavage, lasting $3 \mathrm{~h}$. The rectal effluent from this final lavage was combined with any stool (usually none) that had been passed since the meal was eaten.

\section{Analysis of samples}

Test meal and rectal effluent were each weighed and then well homogenized in a Waring commercial blender. $10 \mathrm{ml}$ of 2-octonol was added to the rectal effluent as a foam suppressant. $20 \mathrm{ml}$ of homogenate was transferred to acid-washed glass flasks and digested with $20 \mathrm{ml}$ of $16 \mathrm{~N}$ nitric acid to dissolve any insoluble calcium. The homogenate was then brought to $100 \mathrm{ml}$ volume with deionized water in an acid-washed volumetric flask. Duplicate aliquots were analyzed for calcium by atomic spectroscopy (model 2380, Perkin-Elmer Corp., Norwalk, CT). Homogenized but undigested samples were analyzed for PEG by the method of Hyden (10).

\section{Validation studies}

PEG as a marker for recovery of unabsorbed calcium. PEG is water soluble, whereas part of the calcium remaining in the gut $12 \mathrm{~h}$ after the meal is presumably present as insoluble calcium salts. It was not known whether soluble and insoluble substances would be recovered in rectal effluent at similar rates. To evaluate this, we measured recovery of PEG and ${ }^{51} \mathrm{CrCl}_{3}$ when both were ingested with the test meal. ${ }^{51} \mathrm{CrCl}_{3}$ is believed to become partly insoluble during intestinal transit (11). Six subjects were studied with two levels of calcium intake: $290 \mathrm{mg}$ of food calcium and $1,071 \mathrm{mg}$ of calcium $(71 \mathrm{mg}$ of food calcium and 1,000 $\mathrm{mg}$ of calcium as $\mathrm{CaCO}_{3}$ ). The results are shown in Fig. 1. It is evident from these results that $\mathrm{PEG}$ and ${ }^{\mathrm{SI}} \mathrm{CrCl}_{3}$ were recovered pari passu. Total recoveries of PEG and ${ }^{51} \mathrm{CrCl}_{3}$ were $97.8 \pm 2.5 \%$ and $97.9 \pm 1.3 \%$, respectively, with the lower calcium intake, and $100.0 \pm 0.5 \%$ and $98.0 \pm 1.6 \%$, respectively, with the higher calcium intake. Assuming that part of the ${ }^{51} \mathrm{CrCl}_{3}$ in the gut is insoluble, these results suggest that intestinal lavage removes unabsorbed soluble and insoluble substances at the same rate.

Extent of recovery of unabsorbed dietary calcium. Timed recovery of calcium in the rectal effluent is shown in Fig. 1, and it is evident that a small amount of calcium continued to be washed out of the gut by lavage long after complete recovery of the ingested nonabsorbable markers. This continued excretion of calcium in the lavage effluent could represent delayed recovery of unabsorbed meal calcium, recovery of unabsorbed calcium from digestive secretions, or diffusion of calcium from blood into the gut lumen during lavage. To evaluate the source of this continued calcium excretion in the effluent, we performed additional experiments in six subjects.

On one day after the initial lavage, each subject ingested a meal containing $290 \mathrm{mg}$ of calcium. $12 \mathrm{~h}$ later, the subjects underwent the final lavage, and all rectal effluent was collected and analyzed for calcium recovery over time. On another day, the subject underwent the same protocol but ingested only water and PEG (instead of eating the calciumcontaining meal). The patterns of calcium recovery are shown in Fig. 2 (left). After $2 \mathrm{~h}$ of lavage, continued recovery of calcium was similar on the two test days, which suggests that the continued presence of calcium in the lavage effluent beyond $2 \mathrm{~h}$ is not due to delayed recovery of unabsorbed dietary calcium. Therefore, it must represent either recovery of unabsorbed calcium from digestive secretions or calcium that diffuses from blood to lumen during lavage, or both.

A similar experiment was performed using a high calcium diet, and the results are shown in Fig. 2 (right). It required $3 \mathrm{~h}$ of lavage before calcium excretion in the lavage effluent was similar to that when these same subjects had fasted. These results suggest that $3 \mathrm{~h}$ of lavage are necessary to obtain complete recovery of unabsorbed dietary calcium after ingestion of a high calcium diet. When combined with the results shown in Fig. 1, the data suggest that a small amount of unabsorbed dietary calcium may remain in the gut even after virtually all of the nonabsorbable markers in the meal have been recovered. However, 3 $h$ of lavage is sufficient to obtain complete recovery of all unabsorbed dietary calcium, even after the high calcium diet.

It is important to point out that calcium in the lavage effluent after 
a fast probably does not directly reflect the amount of unabsorbed calcium from endogenous digestive secretions. This is because the lavage procedure creates electrochemical gradients favoring passive diffusion of calcium from blood to gut lumen, and at least part of the calcium in the effluent after a fast probably is due to net calcium diffusion across intestinal mucosal cell membranes.

Timing of second lavage. The 12-h interval between meal ingestion and the final lavage allowed ingested and endogenously secreted calcium to be exposed to absorbing mucosa for a standard period of time. Since transit of chyme through the small bowel is completed within 4-6 $\mathrm{h}$ (12), prolonging the interval between meal ingestion and final lavage would increase exposure of the calcium load to colonic but not to small bowel mucosa. To evaluate the extent to which prolonging the exposure time would increase calcium absorption, three normal subjects were studied on two test days with either a 12- or 24-h interval between meal ingestion ( $852 \mathrm{mg}$ of dietary calcium intake) and final lavage. With the 12-h interval, the lavage effluent contained $739 \pm 43 \mathrm{mg}$ of calcium, whereas with the 24-h interval, the effluent contained $696 \pm 35 \mathrm{mg}$ of calcium. Since the amount of calcium in the final washout was only slightly less with the 24-h interval, these results are compatible with the concept (13) that most calcium absorption normally takes place from the small bowel rather than from the colon.

Sensitivity of the technique. Nine normal subjects were studied on four test days in random order. On the four days they either fasted in between the two lavage periods, or ingested the $71-\mathrm{mg}$ calcium meal plus either 250,500 , or $1,000 \mathrm{mg}$ of calcium as the carbonate. The results for each subject are shown in Table II. With one exception (subject L.Y.), there was a progressive increase in calcium absorption as dietary calcium was increased. Mean absorption was statistically significantly higher with each increment in dietary calcium intake. These

Table II. Calcium Absorption from Diets Containing Different Amounts of Calcium

\begin{tabular}{llccc}
\hline & & \multicolumn{3}{c}{ Net calcium absorption* } \\
\cline { 3 - 5 } Subject & $\begin{array}{l}\text { Calcium in effluent } \\
\text { after fast }\end{array}$ & $\begin{array}{l}321 \mathrm{mg} \\
\text { Intake }\end{array}$ & $\begin{array}{l}571 \mathrm{mg} \\
\text { Intake }\end{array}$ & $\begin{array}{l}1071 \mathrm{mg} \\
\text { Intake }\end{array}$ \\
\hline & $m g$ & $m g$ & $m g$ & $m g$ \\
L.Y. & 61 & 23 & 152 & 60 \\
G.E. & 27 & 40 & 78 & 184 \\
D.G. & 36 & -24 & 196 & 281 \\
J.C. & 52 & 161 & 168 & 489 \\
J.T. & 36 & 39 & 166 & 304 \\
S.H. & 38 & 51 & 107 & 212 \\
C.S.A. & 79 & 216 & 356 & 440 \\
G.C. & 34 & 160 & 261 & 383 \\
C.S.F. & 29 & 144 & 298 & 507 \\
Mean & 44 & 90 & $198 \ddagger$ & $318 \S$ \\
SD & 17 & 81 & 90 & 150 \\
SE & 6 & 27 & 30 & 50 \\
& & & & \\
\hline
\end{tabular}

* Calcium absorption calculated according to formula in Methods. $\ddagger P<0.005$ when compared with $321 \mathrm{mg}$ calcium intake.

$\S P<0.02$ when compared with the $571 \mathrm{mg}$ intake. results show that the technique can readily detect differences in calcium absorption when small groups of subjects are studied. The reason for the aberrant result in subject L.Y. is unknown.

\section{Effect of lavage on intestinal absorption}

Since all experiments involved intestinal lavage, any effect of lavage per se was constant and hopefully should not influence conclusions about the variable (gastric acidity) being studied. However, with regard to the extent to which this new method for measuring calcium absorption can be considered physiological, it was desirable to evaluate the effect of lavage on absorption. This was done by measuring jejunal absorption with the triple-lumen tube, constant perfusion technique (14-16); subjects were studied twice, once when they had been subjected to lavage, and once when they had not. On the lavage test day, the jejunal perfusion experiments were started $4 \mathrm{~h}$ after finishing the lavage, which corresponds to the time when the test meal would have been eaten if dietary calcium absorption had been measured.

As shown in Table III, intestinal lavage had no statistically significant effect on calcium fluxes. The mean value for net calcium absorption was somewhat lower after lavage, but this was mainly accounted for by a large difference in one of the 12 subjects, rather than by any consistent effect. If this one subject were excluded, mean net calcium absorption rates without and with lavage for the remaining 11 subjects were 0.22 and $0.20 \mathrm{mmol} / \mathrm{h}$ per $30 \mathrm{~cm}$, respectively.

As also shown in Table III, phosphate, D-xylose, glucose, sodium, and bicarbonate absorption in the jejunum were not affected to a statistically significant extent by gastrointestinal lavage. Water, chloride, and potassium absorption were also unaffected (data not shown)

\section{Results}

Net calcium absorption from food and from two calcium salts. Six subjects were studied in random sequence, and the results are shown in Table IV. When calcium intake was zero, the lavage effluent contained $42 \mathrm{mg}$ of calcium. The origin and significance of this calcium was discussed in Methods.

When the ingested meal contained $71 \mathrm{mg}$ of calcium, the amount of calcium in the effluent was $110 \mathrm{mg}$. After correcting for calcium excretion not related to the meal $(41 \mathrm{mg})$, net calcium absorption after ingesting the $71 \mathrm{mg}$ calcium meal was negligible (3 mg). When calcium intake was $1,071 \mathrm{mg}$, as supplemented with either calcium carbonate or calcium citrate, net calcium absorption was 255 and $310 \mathrm{mg}$, respectively (not significantly different by paired $t$ test). When calcium intake was increased to $852 \mathrm{mg}$ by milk and cheese, $132 \mathrm{mg}$ of calcium was absorbed.

Mean percent recoveries of PEG are shown in the final column of Table IV.

Effect of cimetidine on net calcium absorption. To assess the effect of reduced gastric acid secretion on net calcium absorption, we studied these same six subjects with and without cimetidine ( $600 \mathrm{mg} 30 \mathrm{~min}$ before the meal was eaten). As shown in Fig. 3 , cimetidine had no significant effect on calcium absorption, whether the subject ingested the high calcium meal $(852 \mathrm{mg})$ alone, the low calcium meal plus calcium carbonate $(1,071 \mathrm{mg})$, or the low calcium meal plus calcium citrate $(1,071 \mathrm{mg})$. 
Table III. Effect of Gastrointestinal Lavage on Jejunal Absorption Studied with the Triple-Lumen Tube Method

\begin{tabular}{|c|c|c|c|}
\hline & $\begin{array}{l}\text { No. of paired } \\
\text { experiments }\end{array}$ & No lavage & Lavage \\
\hline $\begin{array}{l}\text { Calcium fluxes } \\
\qquad(\mathrm{mmol} / \mathrm{h} / 30 \mathrm{~cm})\end{array}$ & 12 & & \\
\hline Net & & $0.21 \pm 0.02$ & $0.17 \pm 0.04$ \\
\hline Lumen-to-plasma & & $0.29 \pm 0.03$ & $0.24 \pm 0.03$ \\
\hline Plasma-to-lumen & & $0.08 \pm 0.02$ & $0.07 \pm 0.04$ \\
\hline $\begin{array}{l}\text { Phosphate absorption } \\
\qquad(\mathrm{mmol} / \mathrm{h} / 30 \mathrm{~cm})\end{array}$ & 5 & $0.37 \pm 0.06$ & $0.38 \pm 0.04$ \\
\hline $\begin{array}{l}\text { D-xylose absorption } \\
\qquad(\mathrm{mmol} / \mathrm{h} / 30 \mathrm{~cm})\end{array}$ & 7 & $1.56 \pm 0.14$ & $1.67 \pm 0.08$ \\
\hline $\begin{array}{l}\text { Glucose absorption } \\
\qquad(\mathrm{mmol} / \mathrm{h} / 30 \mathrm{~cm})\end{array}$ & 11 & $21.7 \pm 1.1$ & $22.0 \pm 0.8$ \\
\hline $\begin{array}{l}\text { Sodium absorption } \\
\qquad(\mathrm{meq} / \mathrm{h} / 30 \mathrm{~cm})\end{array}$ & & & \\
\hline Without glucose & 7 & $13.0 \pm 2.4$ & $10.6 \pm 1.8$ \\
\hline With glucose & 11 & $19.7 \pm 1.7$ & $19.7 \pm 2.7$ \\
\hline $\begin{array}{l}\text { Bicarbonate absorption } \\
(\mathrm{meq} / \mathrm{h} / 30 \mathrm{~cm})\end{array}$ & 7 & $8.1 \pm 0.6$ & $8.7 \pm 1.2$ \\
\hline
\end{tabular}

Calcium absorption was measured during perfusion of $5 \mathrm{mM}$ calcium gluconate, labeled with ${ }^{47} \mathrm{Ca}$ (14). Phosphate absorption was studied during perfusion of $2.5 \mathrm{mM}$ sodium phosphate (15). Electrolyte and xylose absorptions were measured during perfusion of a balanced electrolyte solution (16). For study of glucose absorption, a $65 \mathrm{mM}$ glucose solution was perfused; the concentration of electrolytes was reduced to make the test solution isoosmolar to plasma. The concentration of perfused solutes and the mean concentration of solutes in the 30-cm test segment without and with lavage were as follows: Calcium (millimolar): 5, 4.10, 4.14; phosphate (millimolar): 2.5, 2.21, 2.19; D-xylose (millimolar): 10, 6.47, 6.41; glucose (millimolar): 65 , 31.0, 30.3; sodium (milliequivalents per liter) without glucose: 140 , 139, 139; sodium (milliequivalents per liter) with glucose: 105, 121, 121; bicarbonate (milliequivalents per liter): $40.0,18.5,19.4$. None of these concentration differences were statistically significant, and none of the differences in absorption rates shown in the table were statistically significant.

On separate test days, the extent to which cimetidine reduced gastric acidity was assessed in six subjects (four subjects ingested the low calcium meal alone [71 mg], and two ingested the low calcium meal plus two oyster shell tablets [total $1,071 \mathrm{mg}$ of calcium]). Gastric contents were sampled (via a nasogastric tube) every $15 \mathrm{~min}$ for $3 \mathrm{~h}$ after the meal was ingested. Mean gastric $\mathrm{pH}$ after the low calcium meal increased from $2.79 \pm 0.2$ without cimetidine to $5.56 \pm 0.2$ with cimetidine. After the meal plus oyster shell tablets, mean gastric $\mathrm{pH}$ increased with cimetidine from $3.70 \pm 0.2$ to $4.92 \pm 0.2$.

Studies in a patient with pernicious anemia. Since even a large dose of cimetidine did not totally eliminate gastric acidity, the results with cimetidine do not exclude an effect of gastric acidity on calcium absorption. Therefore, we studied a patient with treated pernicious anemia and proven gastric achlorhydria ( $\mathrm{pH}>7.4$ after maximal stimulation with pentagastrin). The results in this patient are also shown in Fig. 3. Her calcium absorption was modestly higher than the mean value for six normal subjects.

We initially assumed that the $\mathrm{pH}$ of gastric contents in this patient would remain near 7.4 after food was eaten. However, this patient's mean gastric $\mathrm{pH}$ after she ate the low calcium meal was $5.75 \pm 0.09$ (methods for measuring gastric acidity identical to that described above). We then suspected that the acidity of the food constituents in the meal itself might be responsible for the acid pH of her gastric contents. Our suspicions were confirmed when we determined in vitro that the $\mathrm{pH}$ of the homogenized test meal was 5.4.

Although these results argued against an important role for gastric acid secretion in calcium absorption, they did not rule out a role for the acidity of the gastric contents.

Studies with in vivo titration to maintain gastric pH at 7.4 and 3.0. We studied eight subjects on two test days. On each day, the subjects ingested $600 \mathrm{mg}$ of cimetidine. 30 min later, the low calcium meal (homogenized) ${ }^{3}$ was infused into the stomach, followed 30 min later by ingestion of two oyster shell tablets (total calcium intake, $1,063 \mathrm{mg}$ ). On one test day, the $\mathrm{pH}$ of gastric contents was maintained at $\mathrm{pH} 7.4$ for $4 \mathrm{~h}$ by in vivo titration (17) with $0.3 \mathrm{~N} \mathrm{NaHCO}_{3}$. Since acid secretion was suppressed by cimetidine, only $37 \pm 6 \mathrm{ml}$ of $\mathrm{NaHCO}_{3}$ was required to keep gastric $\mathrm{pH}$ at 7.4 for the 4 -h period. On the other test day, the $\mathrm{pH}$ of gastric contents was maintained at $\mathrm{pH}$ 3.0 for $4 \mathrm{~h}$ by in vivo titration with $0.1 \mathrm{~N} \mathrm{HCl}$. The volume of $\mathrm{HCl}$ required to maintain $\mathrm{pH}$ at 3.0 for the 4-h period was $150 \pm 30 \mathrm{ml}$. Net calcium absorption was measured as described above. The results are shown in Table $\mathrm{V}$. The absorption of calcium was similar on the two test days, suggesting that absorption of dietary calcium is not increased by increasing intragastric acidity from $\mathrm{pH} 7.4$ to $\mathrm{pH}$ 3.0. This interpretation of these results is dependent on the assumption that ingested calcium was emptied from the stomach during the 4-h period of intragastric titration to $\mathrm{pH}$ 7.4. To evaluate this, five subjects were studied during intragastric titration to $\mathrm{pH} 7.4$ for $4 \mathrm{~h}$. At the end of this time, their stomachs were irrigated for $20 \mathrm{~min}$ on four consecutive occasions with $250 \mathrm{ml}$ of a dilute hydrochloric acid solution ( $\mathrm{pH} 2.5$ ). Total calcium recovered in the combined wash solutions averaged $20.9 \pm 7.8 \mathrm{mg}$. Thus, the amount of calcium remaining in the stomach at the end of in vitro titration to $\mathrm{pH} 7.4$ was small compared with the 1,063 mg of ingested calcium, i.e., almost all of the ingested calcium left in the stomach while the intragastric $\mathrm{pH}$ was 7.4.

In three additional studies, $1 \mathrm{ml}$ of gastric contents was

3. Lettuce and salad dressing were eliminated from the low calcium meal for these experiments because their inclusion made the homogenate too thick to infuse through the Andersen tube (H. W. Andersen Products, Inc., Oyster Bay, NY). 
Table IV. Net Calcium Absorption with Different Dietary Calcium Intakes $(n=6)$

\begin{tabular}{|c|c|c|c|c|}
\hline & Calcium intake & $\begin{array}{l}\text { Calcium in } \\
\text { effluent }\end{array}$ & $\begin{array}{l}\text { Net calcium } \\
\text { absorption }\end{array}$ & PEG recovery \\
\hline & $m g$ & $m g$ & $m g$ & \% of intake \\
\hline Fast & 0 & $42 \pm 5$ & - & $100.5 \pm 2.2$ \\
\hline Low calcium meal & 71 & $110 \pm 23$ & $3 \pm 22$ & $102.4 \pm 2.1$ \\
\hline Low calcium meal + oyster shell $\mathrm{CaCO}_{3}$ tablets & 1,071 & $860 \pm 61$ & $255 \pm 58$ & $100.9 \pm 0.6$ \\
\hline Low calcium meal + calcium citrate in solution & 1,071 & $802 \pm 48$ & $310 \pm 52$ & $100.2 \pm 0.5$ \\
\hline High calcium meal & 852 & $760 \pm 49$ & $132 \pm 50$ & $97.9 \pm 2.0$ \\
\hline
\end{tabular}

Results are given as mean \pm SEM.

saved each time intragastric $\mathrm{pH}$ was measured for intragastric titration (samples taken every 2-3 min); these were pooled at 30-min intervals over the 4-h period, and analyzed for soluble and total calcium concentration. When intragastric $\mathrm{pH}$ was maintained at pH 7.4 (two studies), only $3 \%$ of gastric content calcium was soluble, whereas at $\mathrm{pH} 3.0$ (one study), $86 \%$ of gastric content calcium was soluble.

It will be noted that net absorption of calcium was higher in Table $\mathrm{V}$ than in Table IV. There are two possible explanations. First, some of the subjects that took part in the first experiment did not take part in the second, and vice versa. As shown in Table II, absorption in different normal subjects can vary widely. Second, the meal shown in Table IV contained lettuce and salad dressing, and one of these foods may reduce calcium absorption. Finally, the food was homogenized in the experiment shown in Table $\mathrm{V}$, and it is possible that this may enhance calcium absorption.

\section{Discussion}

For reasons enumerated in the Introduction, it seemed important to establish the importance of gastric acid secretion and gastric acidity on intestinal absorption of dietary calcium. None of the

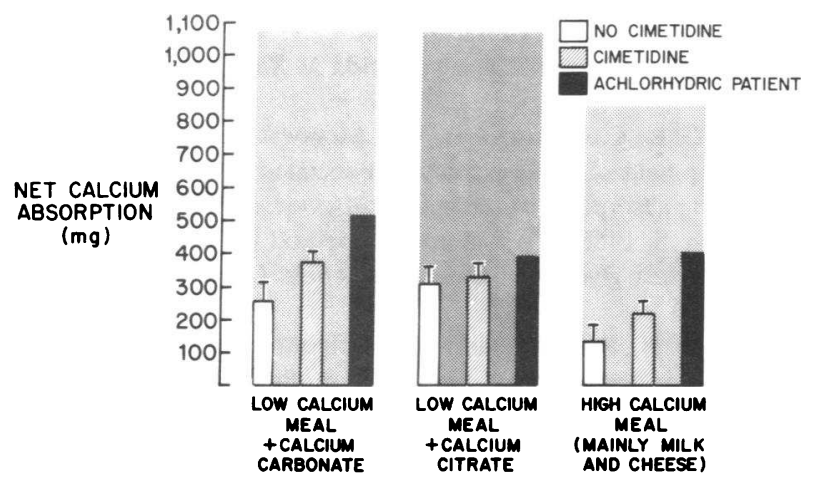

Figure 3. Effect of cimetidine and gastric achlorhydria on net calcium absorption. Six normal subjects and one patient with pernicious anemia and proven gastric achlorhydria were studied. Results as mean \pm SEM. previously described methods for measuring calcium absorption seemed suitable for this purpose, being either too time-consuming and expensive (classic balance method) or dependent on the unproven reliability of various isotopic methods that do not actually measure net calcium absorption. We therefore developed and attempted to validate a new method, in which net absorption of dietary calcium is measured after a single meal. The method requires a preliminary and final washout of the gastrointestinal tract by lavage with a special electrolyte solution, and the effect of such lavage on calcium absorption as measured by this technique needs to be considered. However, there is no a priori reason to believe that this lavage would disturb small bowel digestive or absorptive processes, since the lavage fluid is isotonic to plasma and is not associated with net intestinal absorption or secretion (9). The small bowel is normally clear of debris in the fasting state; hence, further cleansing with this inert lavage solution would not be expected to induce physiological derangements. Furthermore, we have recently shown that nutrient absorption measured by a similar method gives almost identical results as are obtained by the classic balance method (18). Finally, as part of our validation experiments (see Methods), we found that lavage did not alter subsequent jejunal absorption of calcium, phosphate, electrolytes, or sugars as measured by the triple-lumen perfusion method. Thus, we do not believe that the lavage procedure as used here alters small bowel absorptive processes. The lavage does remove bacteria from the colon, but colonic bacteria are generally thought not to play an important role in calcium absorption. The method is easy to employ and is well tolerated by normal subjects and by patients with various diseases (unpublished studies from our laboratory).

Using this method, we were not able to confirm the commonly held opinion that gastric acid secretion and gastric acidity play a role in determining the amount of dietary calcium that is absorbed. Thus, a large dose of cimetidine did not alter the amount of calcium that was absorbed by normal subjects, and a patient with gastric atrophy (who secreted no acid) absorbed calcium normally (Fig. 3). These conclusions apply regardless of the form in which calcium was ingested, i.e., milk and cheese, insoluble calcium carbonate, or soluble calcium citrate. Furthermore, absorption of calcium from calcium carbonate was 
Table V. Net Calcium Absorption when Gastric pH Is Maintained at 7.4 or 3.0 by In Vivo Intragastric Titration

\begin{tabular}{llllr}
\hline & Calcium intake & $\begin{array}{l}\text { Calcium in } \\
\text { effluent }\end{array}$ & $\begin{array}{l}\text { Net calcium } \\
\text { absorption }\end{array}$ & PEG recovery \\
\hline & $m g$ & $m g$ & $m g$ & \% of intake \\
$\begin{array}{l}\text { Fast } \\
\text { Gastric pH } \\
7.4\end{array}$ & 0 & $41 \pm 4$ & - & $99.3 \pm 1.4$ \\
$\begin{array}{l}\text { Gastric pH } \\
3.0\end{array}$ & 1,063 & $645 \pm 87$ & $458 \pm 87$ & $100.2 \pm 1.1$ \\
\hline
\end{tabular}

Results are given as mean \pm SEM. Calcium intake was $1,063 \mathrm{mg}$, mainly in the form of calcium carbonate $(n=8)$ (low calcium meal [minus lettuce and salad dressing] supplemented with $1,000 \mathrm{mg}$ of calcium as $\mathrm{CaCO}_{3}$ ).

the same when gastric pH was maintained at 7.4 as at 3.0 by in vivo titration, showing that the level of gastric acidity has no discernable effect on absorption of dietary calcium.

Our results raise an interesting but puzzling question. If calcium in calcium carbonate must be solubilized before absorption can occur, how is this critical solubilization achieved in the total absence of gastric acid? One possibility is acid secretion by the mucosal cells of the proximal small intestine. Previous work has revealed that the natural $\mathrm{pH}$ of the jejunal contents is $\sim 6.1$ (19), and that this is probably due to secretion of hydrogen ions (20). As illustrated by the in vitro experiment shown in Table I, at pH 6 a considerable amount of calcium carbonate will go into solution. Therefore, it is possible that acid secretion by jejunal mucosa, which is not inhibited by cimetidine (21), might serve to solubilize calcium salts and make the calcium available for absorption by intestinal mucosal cells. A second possible explanation is the putative microclimate of intestinal mucosal cells. Isolated human intestinal cells have an electrophoretic mobility consistent with a fixed negative surface charge (22), and it has been suggested that these charges bind hydrogen ions and create a microclimate of high acidity adjacent to the brush border membrane (23). This localized area of high acidity, estimated to be $\mathrm{pH} 5.3$, could also serve to solubilize calcium carbonate. A third possible explanation for the seeming unimportance of gastric acid is that calcium carbonate, while insoluble in water, may become soluble in biliary or pancreatic fluids. Bile acids can increase the in vitro solubility of $\mathrm{CaHPO}_{4}$ and enhance the absorption of calcium in chicks independent of the action of vitamin $D(24,25)$. However, in unpublished results in our laboratory, we have been unable to show that solutions containing pancreatic enzymes and bile acids enhance the solubility of calcium carbonate.

Although the opinion that gastric acidity plays an important role in absorption of dietary calcium is widely held, this has been based more on reasonable logic than on experimental evidence. To the best of our knowledge, the only previous experiment bearing directly on this question was the study of
Ivanovich et al. (4). These workers measured calcium absorption using an isotopic method, and found absorption of ${ }^{45} \mathrm{CaCO}_{3}$ to be decreased in four patients with hypo- or achlorhydria when compared to controls. We are unable to explain the discrepancy between this report and our own results. However, we do not believe that these results by Ivanovich et al., using the indirect measurement of calcium absorption, cast serious doubt on our finding that gastric acid secretion and gastric acidity do not normally play an important role in the net absorption of dietary calcium.

\section{Acknowledgments}

This work was supported by grant AM-26794 from the National Institute of Arthritis, Metabolism and Digestive Diseases (NIAMDD) grant AM17328 to CURE (Center for Ulcer, Research and Education) from NIAMDD; Clinical Investigator Award grant AM-01204 from the National Institute of Arthritis, Diabetes, Digestive and Kidney Diseases; and the Southwestern Medical Foundation's Abbie K. Dreyfuss Fund and the Holley-Franklin Medical Research Trust Fund, Dallas, TX.

\section{References}

1. Nordin, B. E. C. 1968. Measurement and meaning of calcium absorption. Gastroenterology. 54:294-301.

2. Schachter, D., E. B. Dowdle, and H. Schenker. 1960. Active transport of calcium by the small intestine of the rat. Am. J. Physiol. 198:263-268.

3. Smith, R. H., and A. B. McAllan. 1966. Binding of magnesium and calcium in the contents of the small intestine of the calf. $\mathrm{Br}$. $J$. Nutr. 20:703-718.

4. Ivanovich, P., H. Fellows, and C. Rich. 1967. The absorption of calcium carbonate. Ann. Intern. Med. 66:917-923.

5. Clarkson, E. M., S. J. McDonald, and H. E. DeWardner. 1966. The effect of high intake of calcium carbonate in normal subjects and patients with chronic renal failure. Clin. Res. 30:425-438.

6. The Medical Letter. Calcium for postmenopausal osteoporosis. M. Abramowicz, editor. 1982. 24:105-106.

7. Baron, J. H. 1963. Studies of basal and peak acid output with an augmented histamine test. Gut. 4:136-144.

8. Fordtran, J. S., S. G. Morawski, and C. T. Richardson. 1973. In vivo and in vitro evaluation of liquid antacids. $N$. Engl. J. Med. 288:923928.

9. Davis, G. R., C. A. Santa Ana, S. G. Morawski, and J. S. Fordtran. 1980. Development of a lavage solution associated with minimal water and electrolyte absorption or secretion. Gastroenterology. 78:991-995.

10. Hyden, S. 1955. A turbidometric method for determination of higher polyethylene glycols in biological materials. Lantbrukshogsk. Ann. 22:139-145.

11. Fromm, H., P. J. Thomas, and A. F. Hofmann. 1973. Sensitivity and specificity in tests of distal ileal function. Prospective comparison of bile acid and vitamin $\mathrm{B}_{12}$ absorption in ileal resection patients. Gastroenterology. 68:1077-1090.

12. Read, N. W., C. A. Miles, D. Fisher, A. M. Holgate, N. D. Kime, M. A. Mitchell, A. M. Reeve, T. B. Roche, and M. Walker. 1980. Transit of a meal through the stomach, small intestine and colon in normal subjects and its role in the pathogenesis of diarrhea. Gastroenterology. 79:1276-1282. 
13. Krane, S. M., and J. T. Potts, Jr. 1977. Skeletal remodeling and factors influencing bone and mineral metabolism. In Harrison's Principles of Internal Medicine. G. W. Thorn, R. D. Adams, E. Braunwald, K. J. Isselbacher, and R. E. Petersdorf, editors. McGraw-Hill Book Co., Inc., New York. 2005.

14. Vergne-Marini, P., T. F. Parker, C. Y. C. Pak, A. R. Hull, H. F. DeLuca, and J. S. Fordtran. 1976. Jejunal and ileal calcium absorption in patients with chronic renal disease: Effect of $1 \alpha$-hydroxycholecalciferol. J. Clin. Invest. 57:861-866.

15. Davis, G. R., J. E. Zerwekh, T. F. Parker, G. J. Krejs, C. Y. C. Pak, and J. S. Fordtran. 1983. Absorption of phosphate in the jejunum of patients with chronic renal failure before and after correction of vitamin D deficiency. Gastroenterology. 85:908-916.

16. Krejs, G. J., J. H. Walsh, S. G. Morawski, and J. S. Fordtran. 1977. Intractable diarrhea: intestinal perfusion studies and plasma VIP concentrations in patients with pancreatic cholera syndrome and surreptitious ingestion of laxatives and diuretics. Am. J. Dig. Dis. 22:280292

17. Richardson, C. T., J. H. Walsh, K. A. Cooper, M. Feldman, and J. S. Fordtran. 1977. Studies on the role of cephalic-vagal stimulation in the acid secretory response to eating in normal human subjects. $J$. Clin. Invest. 60:435-441.
18. Bo-Linn, G. W., C. A. Santa Ana, S. G. Morawski, and J. S. Fordtran. 1982. Starch blockers: their effect on calorie absorption from a high-starch meal. N. Engl. J. Med. 307:1413-1416.

19. McBee, L. C., and A. B. Hastings. 1942. The carbon dioxide tension and acid-base balance of jejunal secretions in man. J. Biol. Chem. 142:893-902.

20. Turnberg, L. A., J. S. Fordtran, N. W. Carter, and F. C. Rector. 1970. Mechanism of bicarbonate absorption and its relationship to sodium transport in the human jejunum. J. Clin. Invest. 49:548-556.

21. Davis, G. R., C. A. Santa Ana, S. G. Morawski, and J. S. Fordtran. 1980. Active chloride secretion in normal human jejunum. J. Clin. Invest. 66:1326-1333.

22. Vassar, P. S. 1963. The electric charge density of human tumor cell surfaces. Lab. Invest. 12:1072-1077.

23. Hogben, C. A. M., D. J. Tocco, B. B. Brodie, and S. S. Schanker. 1959. On the mechanism of intestinal absorption of drugs. J. Pharmacol. Exp. Ther. 125:275-282.

24. Webling, D. D'A, and E. S. Holdsworth. 1965. The effect of bile, bile acids, and detergents on calcium absorption in the chick. Biochem. J. 97:408-421.

25. Webling, D. D’A, and E. S. Holdsworth. 1966. Bile salts and calcium absorption. Biochem. J. 100:652-660. 